Article

\title{
Influence of Soil Characteristics on Wood Biodeterioration by Brown Rot Fungi
}

\author{
Javier Ribera ${ }^{1, *(\mathbb{D})}$, Elisabeth Michel ${ }^{2}$ and Francis W. M. R. Schwarze ${ }^{1}$ \\ 1 Laboratory for Cellulose \& Wood Materials, Empa, 5, 9014 St. Gallen, Switzerland; \\ francis.schwarze@empa.ch \\ 2 Laboratory for Advanced Fibers, Empa, 5, 9014 St. Gallen, Switzerland; elisabeth.michel@empa.ch \\ * Correspondence: javier.ribera@empa.ch
}

Received: 21 November 2020; Accepted: 9 December 2020; Published: 10 December 2020

\begin{abstract}
Soil conditions can directly influence the inoculum potential of wood decay fungi, which is likely to be a major factor in the premature failure of utility poles across Europe. The objective of our study was to assess the influence of soil $\mathrm{pH}$, humic acid and iron on wood decay. For this purpose, we incubated Fe-impregnated wood specimens on artificial medium to evaluate the influence of the metal on the activity of brown rot fungi. Moreover, the impact of $\mathrm{Cu}$-leaching from impregnated wood specimens that were exposed to humic acid solutions was measured. In addition, weight losses caused by brown rot fungi in impregnated wood pole segments and stiffness (Young's modulus of Elasticity) of Cu-impregnated wood specimens were quantified. The $\mathrm{pH}$ measurements showed that the soil samples were slightly acid $(\mathrm{pH}=6.7 \pm 0.7)$. In comparison to non-impregnated controls, the Fe-impregnated samples significantly increased weight losses by brown rot fungi $(>30-40 \%)$. In the presence of humic acid the release of copper from chromium-free wood preservatives (up to $143.34 \mathrm{mg} \mathrm{L}^{-1}$ ) was enhanced. Weight losses in impregnated wood segments by brown rot fungi ranged from 5.3 to $20.4 \%$. The recorded reduction in stiffness by brown rot fungi ranged from approximately 3.96 to $55.52 \%$ for $\mathrm{Cu}$-impregnated wood specimens after 12 weeks. Our study shows that the $\mathrm{pH}$, humic acid, iron content and selected wood preservatives greatly influence susceptibility of impregnated wood to brown rot fungi during ground contact.
\end{abstract}

Keywords: brown rot fungi; wood preservatives; humic acid; $\mathrm{pH}$; iron; utility poles

\section{Introduction}

Soil-based ecosystems are composed of a range of solid, liquid and gaseous phases. The balance between these physicochemical properties is one of the most important factors for the structure and distribution of microbial communities in soils. In soil formation, microbial diversity and its interaction are directly related to the recycling of nutrients, organic matter decomposition rates, biological population regulations and the degradation of toxic compounds [1]. Depending on the type of soil its biological diversity maybe composed of up to 8800 different genome species [2]. In comparison to other soil organisms, bacteria and fungi are by far the most important microbiota and their particular interactions form symbiotic networks in form of microhabitats and mycospheres [3]. Moreover, root traits also influence soil $\mathrm{C}$ cycling through influencing the growth of fungi over bacteria, such as high lignin and low root $\mathrm{N}$ content, promote soil $\mathrm{C}$ sequestration $[4,5]$. Human activities such as intensive agriculture and industrial residues/contaminants also have an important influence on soil compositions and thus its ecological biodiversity [6]. Soil characteristics tend to react slowly to drastic changes in land use and management [7]; therefore, the development of microbial-soil ecosystems is directly related to coevolution and its adaptation to the environmental changes and external influences [2,8-10]. 
Traditionally, wood has been one of the most used construction materials due to its abundancy, strength-to-weight ratio, production costs and environmental benefits. However, as wood is biodegradable it has a limited service life and requires additional protection for ground contact applications [11-13]. It is a mandatory requirement to impregnate wood products in ground contact for protection against microorganisms [12,13]. In 2013, the European Union put new biocide regulations in place, which significantly increase the safety and simplicity requirements of biocides used and placed on the EU market. In recent years, the wood protection industry has started to use $\mathrm{Cr}$ - and boron-free wood products and to develop more environmentally friendly wood modification methods [14-17]. In this context, the exposure of chemically-treated wood e.g., utility poles to soil microorganisms has resulted in the development of several heavy metal tolerance mechanisms. It is believed that complex interactions between the biotic and abiotic environment occur during the degradation of $\mathrm{Cu}$-impregnated wood. However, to date, the exact mechanisms are not fully understood. A number of different mechanisms for metal detoxification by wood decay fungi during colonisation of preservative treated wood have been postulated; (i) the oxidative attack by hydroxyl radicals produced via the fungal Fenton reaction, which results in the fragmentation of cellulose and hemicellulose as well as the oxidative modification of lignin [18-20]. (ii) The metabolic system of glucose via glycolysis results in the production of oxalate as an end product which is released into the substrate and subsequently changes the $\mathrm{pH}$ and also reacts with metal ions to form oxalate complexes [21-23]. (iii) Melanisation of the outer cortex layers of fungal structures (hyphae, spores) which results in the immobilisation of metal ions from their surface and plays a key role in the longevity and defence against potential antagonists [24,25]. The combination of such bioprocesses changes the physical, chemical and structural properties of wood [26] allowing hyphae to colonize and degrade the wood more efficiently [27,28] subsequently altering wood strength and $\mathrm{pH}$ [29].

In natural environments, the complexity of the interactions between soil characteristics and metal ions [30], leaching from wood preservatives [17] and adaptation of fungal communities have to be considered $[8,9]$. The objective of this study was to assess the influence of soil $\mathrm{pH}$, humic acid and iron on wood decay. For this purpose, we assessed the $\mathrm{pH}$ of 50 soil samples with a high fungal activity from different sites in Switzerland where early failures of utility poles had been recorded. We then measured the influence of humic acid on $\mathrm{Cu}$-leaching from wood specimens that had been impregnated with four Cu-based preservatives (copper-chromium (CC), copper-chromium-boron (CCB), Alkaline Copper Quaternary (ACQ), Bis-(N-cyclohexyldiazeniumdioxy)-copper (Cu-HDO)). Finally, Fe-treated wood specimens were studied to evaluate the influence of the metal on the activity of brown rot fungi. Additionally, weight losses caused by brown rot fungi in impregnated wood segments and stiffness of Cu-impregnated wood specimens were quantified.

\section{Materials and Methods}

\subsection{Sites and Soil $p H$ from Which Decayed Utility Poles Were Collected}

For studying the influence of the $\mathrm{pH}$ of soils, soil samples were collected from 50 different sites in Switzerland from which premature failures of utility poles had been reported [13]. An amount of $1 \mathrm{~kg}$ of soil was collected in close proximity around utility poles and inserted into plastic bags (3 replicates up to a depth of $30 \mathrm{~cm}$ ). Each soil sample was dried at $25^{\circ} \mathrm{C}$ for $48-72 \mathrm{~h}$. The soil was sieved and $10 \mathrm{~g}$ from each sample was placed into Falcon tubes with $25 \mathrm{~mL}$ of an aqueous solution of $1 \mathrm{M} \mathrm{KCl}$ (Sigma-Aldrich, Buchs, Switzerland). Falcon tubes were processed in a shaker at $120 \mathrm{rpm}$ and the $\mathrm{pH}$ was measured after $30 \mathrm{~min}$. The colour appearance of the soil samples was used as an indication for the quality of the soil according to the visual soil evaluation techniques by Emmet-Booth et al. [31] and Guimaraes et al. [32]. 


\subsection{Influence of Iron on Wood Weight Losses by the Isolated Brown Rot Fungi}

Metal sensitivity of the most common isolated brown rot fungi from wood poles in Switzerland and Germany was evaluated on sapwood specimens of Scots pine (Pinus sylvestris L.) according to Ribera et al. [13]. Wood specimens with dimensions of $0.5 \times 0.5 \times 0.2 \mathrm{~cm}^{3}$ were vacuum-pressure impregnated with $\mathrm{FeSO}_{4}$ solutions $(0.000,0.025,0.050,0.075$ and $0.100 \%)$ according to the European Standards EN 807 [33]. Samples were sterilised with ethylene oxide (Sigma-Aldrich) and then placed into Petri dishes containing $20 \mathrm{~mL}$ of $2 \%$ Malt extract agar (Oxoid, Pratteln, Switzerland). One mycelial plug, $5 \mathrm{~mm}$ in diameter, was extracted with sterile a cork borer from the margin of a freshly growing colony of each wood decay basidiomycete (Table 1) and placed into the centre of each Petri dishes. Three biological replicates for each fungus were studied. All cultures were maintained in the dark at $22{ }^{\circ} \mathrm{C}$ and $70 \%$ relative humidity (RH). After 8 weeks, the biomass was carefully removed from the wood surfaces with a brush and the final weight was recorded after drying the samples in the oven at $103{ }^{\circ} \mathrm{C}$ for $24 \mathrm{~h}$.

Table 1. Origin of fungal species used in the present study.

\begin{tabular}{cc}
\hline Brown Rot Fungi & Fungal ID $^{*}$ \\
\hline Antrodia serialis & LT577949 \\
Fibroporia vaillantii & LT577950 \\
Serpula himantioides & LT577951 \\
Gloeophyllum sepiarium & LT577952 \\
Rhodonia placenta & Empa $45^{1}$ \\
\hline
\end{tabular}

* EMBL data bank accession number (The European Molecular Biology Laboratory). ${ }^{1}$ EMPA (Swiss Federal Laboratories for Material Science and Technology-Lerchenfeldstrasse 5, CH-9014, St. Gallen (Switzerland).

\subsection{Effect of Humic Acid Treatment on Leaching of Cu-Based Wood Preservatives}

The effect of humic acid (HA) on the impregnated wood stakes was investigated according to Ribera et al. [16] with the following modifications: wood specimens $\left(2 \mathrm{~T} \times 2 \mathrm{R} \times 8 \mathrm{~L} \mathrm{~cm}^{3}\right)$ were impregnated by vacuum-pressure according to EN 807 [33] with the following retention rates: $21.1 \mathrm{~kg} \mathrm{~m}^{-3} \mathrm{CC}$ (copper-chromium), $26.7 \mathrm{~kg} \mathrm{~m}^{-3} \mathrm{CCB}$ (copper-chromium-boron), $20.3 \mathrm{~kg} \mathrm{~m}^{-3} \mathrm{Cu}-\mathrm{HDO}$ (Bis-(N-cyclohexyldiazeniumdioxy)-copper) and $22.6 \mathrm{~kg} \mathrm{~m}^{-3}$ ACQ (Alkaline Copper Quaternary). After impregnation, the wood specimens were placed into Erlenmeyer flasks containing $0.000 \%, 0.020 \%$, $0.005 \%$ of HA (Sigma-Aldrich) dissolved in $500 \mathrm{~mL}$ of deionized water. Three Erlenmeyer flasks for each combination of impregnated wood specimens and HA concentration were prepared. After 10 days immersion of wood specimens in each solution, the specimens were removed and the leaching of $\mathrm{Cu}$ into water was evaluated with inductively coupled plasma optical emission spectrometry (ICP-OES). Additionally, the $\mathrm{Cu}$ content in the wood specimens was measured before and after water exposure. For this purpose, $1 \mathrm{~g}$ of sawdust from each wood sample was extracted and mixed with $3 \mathrm{~mL}$ of $2 \%$ $\mathrm{HNO}_{3}$ and $1 \mathrm{~mL}$ of $35 \% \mathrm{H}_{2} \mathrm{O}_{2}$. After 10 min digestion in the microwave at 500 Watt, the $\mathrm{Cu}$ content in solution was measured using ICP-OES which subsequently enabled calculation of $\mathrm{Cu}$ leaching from wood in \%.

\subsection{Long Term Exposition Test of Wood Pole Segments}

Scots pine sapwood specimens $\left(15 \mathrm{~T} \times 25 \mathrm{R} \times 5 \mathrm{~L} \mathrm{~mm}^{3}\right)$ were incubated with different brown rot fungi (Table 1) in Kolle culture flasks containing $75 \mathrm{~mL}$ of $4 \%$ MEA for 16 weeks according to EN 113 [34]. A mixture of the incubated wood samples was used as inoculum for autoclaved plastic boxes $(40 \mathrm{~L} \times$ $60 \mathrm{~W} \times 50 \mathrm{H} \mathrm{cm}^{3}$ ) containing $2000 \mathrm{~g}$ of vermiculite, $50 \mathrm{~g}$ of sawdust and $1.5 \mathrm{~L}$ of water. After 12 weeks, wood pole segments ( $25 \mathrm{~cm}$ length and around $17 \mathrm{~cm}$ of diameter) that were impregnated with wood preservative formulations as described above (CC, CCB, Cu-HDO, ACQ) were dried in the oven at $45{ }^{\circ} \mathrm{C}$ for $24 \mathrm{~h}$ and the initial weight was recorded. Then, the wood segments were sterilised with ethylene oxide and placed into separate plastic containers with a mixture of the five brown rot 
fungi. Three biological replicates for each experimental condition were studied. The inoculated boxes were maintained at $22( \pm 1)^{\circ} \mathrm{C}$ and $70 \% \mathrm{RH}$. After 24 months, the wood segments were removed, cleaned from fungal biomass and the weight loss recorded after $24 \mathrm{~h}$ at $45^{\circ} \mathrm{C}$.

\subsection{Influence of Wood Decay on the Stiffness of Wood}

For evaluation of the impact of brown rot fungi on stiffness (Young's modulus of elasticity) of Scots pine wood, seventy-four specimens with dimensions of $15 \times 1.2 \times 0.25 \mathrm{~cm}^{3}$ (47 longitudinal strips) and $12 \times 1.2 \times 0.25 \mathrm{~cm}^{3}$ (27 transversal strips) were excised and prepared for free-free vibration tests of beam elements at the first natural frequency. Wood specimens were impregnated by vacuum-pressure according to EN 807 [33]. Based on former studies with utility poles [16], three different concentrations of CC wood preservative were used $\left(0.0,3.8\right.$ and $\left.37.2 \mathrm{~kg} \mathrm{~m}^{-3}\right)$. After impregnation, all specimens were sterilized with ethylene oxide, and then incubated with A. serialis, S. himantioides and R. placenta (Table 1). Autoclavable plastic containers $\left(40 \times 60 \times 15 \mathrm{~cm}^{3}\right)$ with vermiculite/sawdust were used as described above for the incubation of wood specimens. Three wood specimens impregnated with each preservative concentration were incubated with all fungi for a further 12 weeks and monitored as previously described. After incubation, the specimens were removed from the containers, cleaned with a brush and dried at $50{ }^{\circ} \mathrm{C}$ for 1 week.

The first resonance frequency $(\mathrm{fR})$ and internal damping $(\tan \delta)$ of each wood specimen was determined before and after fungal treatment by a custom developed free-free resonance flexural vibration test [35-37]. Each specimen was supported by cotton threads located at the position of the vibration nodes of the fundamental frequency. They were subjected to forced bending vibration by an electromagnet facing a metallic plate of glued at the end of the specimen. Vibration was emitted by means of an electric magnet device and displacements at the anti-node of the first vibration mode were measured with a laser triangulation displacement sensor. The specific modulus of elasticity $(E / \rho)$ was calculated from the first natural frequency of the specimens, according to the Euler-Bernouilli equation as follows:

$$
\frac{E}{\rho}=\frac{48 \pi^{2} l^{4}}{m_{n}^{4} h^{2}} f_{R n}^{2}
$$

\subsection{Statistical Analysis}

For comparison of the influence of the different study conditions, a Tukey's Honestly Significant Difference (HSD) test was performed $(p<0.05)$. The statistical package SPSS ${ }^{\circledR}$ (Version 22, SPSS Inc., Chicago, IL, USA) was applied for analysis.

\section{Results}

\subsection{Sites and Soil pH from Which Decayed Utility Poles Were Collected}

Soil properties are presented in Table S1. All collected soils showed a brownish-dark appearance with a high amount of organic matter and humic acid substances (Figure 1). Other criteria such as rupture resistance to hand pressing, presence of grass roots enmeshing aggregates, humidity or microbial presence were observed. The $\mathrm{pH}$ measurements of the soil samples collected around utility poles revealed an average $\mathrm{pH}$ of $6.7 \pm 0.7$. No apparent differences between the soil collected around damaged utility poles that were attacked by soft rot fungi $(\mathrm{pH}=6.7 \pm 0.7)$ or damaged by brown rot fungi $(\mathrm{pH}=6.7 \pm 0.7)$ were evident. Isolated fungi from the utility poles in the same sites were mainly associated with brown rot fungi [14]. 


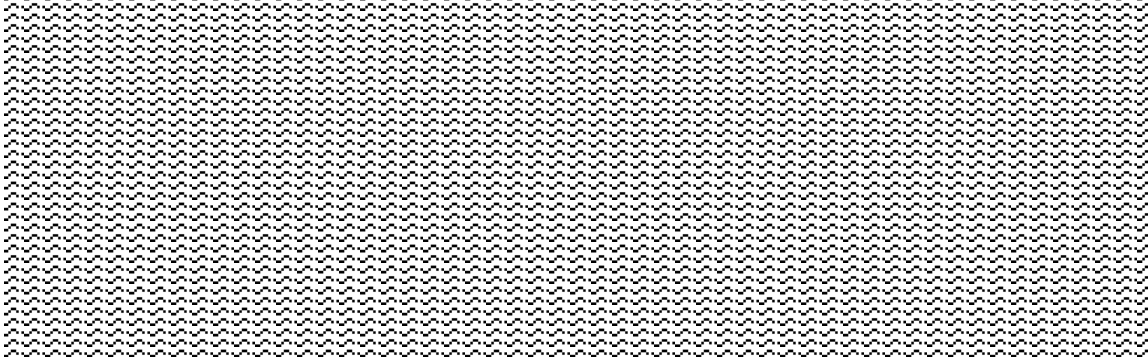

Figure 1. Soil samples collected from: (a); Escholzmatt (Coordinates UTM: 32T 418899; 5196217). (b); Orbe (Coordinates UTM: 32T 311,454; 5,178,043) (c); Zumikon (Coordinates UTM: 32T 471,589; $5,241,894)$.

\subsection{Influence of Iron on Weight Losses by the Isolated Brown Rot Fungi}

Weight losses caused by brown rot fungi in $\mathrm{FeSO}_{4}$-impregnated wood is illustrated in Figure 2. Wood specimens impregnated with $0.025-0.1 \% \mathrm{FeSO}_{4}$ were readily colonised by $A$. serialis, $F$. vaillantii and R. placenta and showed significant weight losses in comparison to controls. However, A. serialis and R. placenta showed only a minor reduction in weight losses in $\mathrm{FeSO}_{4}$ treated wood with $0.075 \%$ and $0.1 \%$, respectively, when compared to lower concentrations $\left(0.025 \%\right.$ and $\left.0.05 \% \mathrm{FeSO}_{4}\right)$. On the contrary, S. himantioides and G. sepiarium did not cause any significant differences in weight losses for all $\mathrm{FeSO}_{4}$ concentrations.

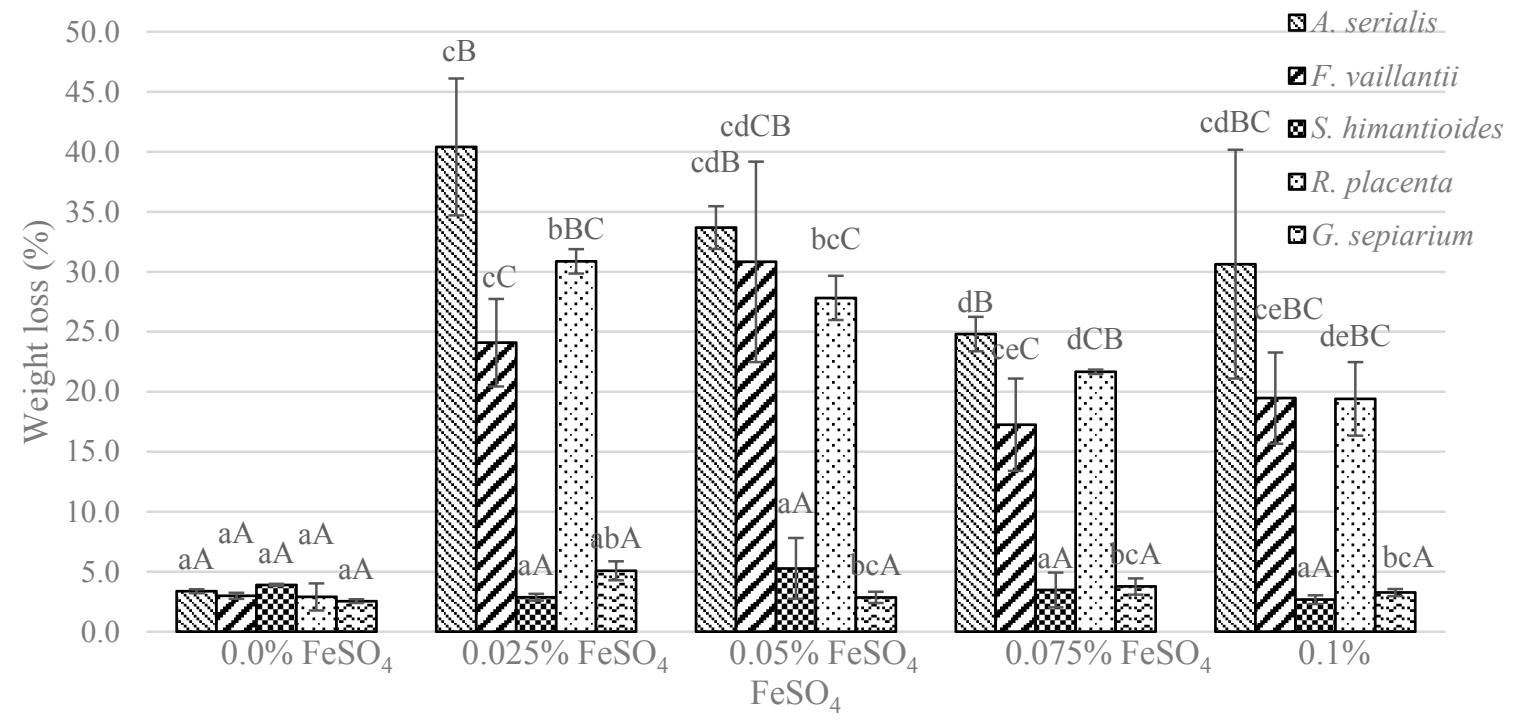

Figure 2. Weight losses by brown rot fungi in Scots pine wood blocks treated with different concentrations of $\mathrm{FeSO}_{4}$ after 12 weeks incubation. Uppercase letters indicate significant differences between weight losses in impregnated wood specimens and the controls. Lowercase letters indicate significant differences between the studied brown rot fungi for each metal concentration. Data are represented as mean \pm SD of three biological replicates $(p<0.05)$.

\subsection{Effect of Humic Acid Treatment on Leaching of Cu-Based Wood Preservatives}

Copper values released into water as well as $\mathrm{Cu}$ values lost by impregnated wood specimens are presented in Table 2. Significant differences of Cu-leaching between all wood preservative treatments were found according to Tukey's test. The amount of Cu-leaching from impregnated wood was significantly higher for $\mathrm{Cr}$-free treated wood specimens (123.23-143.34 mg L ${ }^{-1} \mathrm{Cu}-\mathrm{HDO}$ and 53.96-71.88 $\left.\mathrm{mg} \mathrm{L}^{-1} \mathrm{ACQ}\right)$ than for wood treated with Cr-based formulations (17.36-26.82 $\mathrm{mg} \mathrm{L}^{-1} \mathrm{CC}$ and $29.62-33.61 \mathrm{mg} \mathrm{L}^{-1} \mathrm{CCB}$ ). The influence of $\mathrm{HA}$ in solution was higher for $\mathrm{Cr}$-free wood preservatives (\% Cu-HDO and \% ACQ). The results demonstrated that, in general, low amounts of HA in solution 
$(0.005 \%)$ resulted in a higher release of $\mathrm{Cu}$ from treated wood. Only $\mathrm{Cu}-\mathrm{HDO}$ treated samples released more $\mathrm{Cu}$ when $\mathrm{HA}$ was not present in water.

Table 2. Effect of humic acid on wood preservative leaching from treated wood specimens.

\begin{tabular}{|c|c|c|c|c|c|}
\hline Sample & $\begin{array}{l}\text { Treatment } \\
\text { (HA\%) }\end{array}$ & $\begin{array}{c}\text { Initial Cu in Wood } \\
\left(\mathrm{mg} \mathrm{g}^{-1}\right)\end{array}$ & $\begin{array}{c}\text { Final Cu in Wood } \\
\left(\mathrm{mg} \mathrm{g}^{-1}\right)\end{array}$ & $\begin{array}{c}\text { Cu Leached } \\
(\%)\end{array}$ & $\begin{array}{c}\text { Cu released in Water } \\
\left(\mathrm{mg} \mathrm{L}^{-1}\right)\end{array}$ \\
\hline \multirow{3}{*}{ Control } & 0.000 & $0.00 \pm 0.00$ & $0.00(\mathrm{aA}) \pm 0.00$ & - & $0.00(\mathrm{aA}) \pm 0.00$ \\
\hline & 0.005 & $0.00 \pm 0.00$ & $0.00(\mathrm{aA}) \pm 0.00$ & - & $0.00(\mathrm{aA}) \pm 0.00$ \\
\hline & 0.020 & $0.00 \pm 0.00$ & $0.00(\mathrm{aA}) \pm 0.00$ & - & $0.00(\mathrm{aA}) \pm 0.00$ \\
\hline \multirow{3}{*}{$\mathrm{CC}$} & 0.000 & $5.13 \pm 0.16$ & $4.60(\mathrm{abB}) \pm 0.11$ & 10.27 & $17.36(\mathrm{aB}) \pm 0.83$ \\
\hline & 0.005 & $3.85 \pm 0.27$ & $2.99(\mathrm{cB}) \pm 0.21$ & 22.27 & $19.62(\mathrm{bcB}) \pm 0.54$ \\
\hline & 0.020 & $4.37 \pm 0.31$ & $4.01(\mathrm{aB}) \pm 0.30$ & 8.23 & $26.82(\mathrm{cB}) \pm 1.19$ \\
\hline \multirow{3}{*}{ ССВ } & 0.000 & $6.25 \pm 0.34$ & $5.73(\mathrm{abC}) \pm 0.28$ & 8.42 & $29.62(\mathrm{aC}) \pm 1.16$ \\
\hline & 0.005 & $6.21 \pm 0.22$ & $5.42(\mathrm{bC}) \pm 0.07$ & 12.67 & $33.61(\mathrm{abCB}) \pm 1.21$ \\
\hline & 0.020 & $5.61 \pm 0.15$ & $5.47(\mathrm{cAB}) \pm 0.19$ & 2.44 & $29.85(\mathrm{aB}) \pm 1.00$ \\
\hline \multirow{3}{*}{$\mathrm{Cu}-\mathrm{HDO}$} & 0.000 & $6.75 \pm 0.17$ & $5.39(\mathrm{aD}) \pm 0.14$ & 20.06 & $130.95(\mathrm{aD}) \pm 1.53$ \\
\hline & 0.005 & $6.65 \pm 0.12$ & $5.57(\mathrm{abBC}) \pm 0.15$ & 16.20 & $143.34(\mathrm{abD}) \pm 3.61$ \\
\hline & 0.020 & $6.65 \pm 0.26$ & $5.69(\mathrm{bC}) \pm 0.29$ & 14.44 & $123.23(\mathrm{aC}) \pm 1.82$ \\
\hline \multirow{3}{*}{ ACQ } & 0.000 & $5.39 \pm 0.26$ & $4.76(\mathrm{aB}) \pm 0.33$ & 11.70 & $53.96(\mathrm{aCD}) \pm 1.28$ \\
\hline & 0.005 & $5.38 \pm 0.23$ & $4.23(\mathrm{bcB}) \pm 0.27$ & 21.49 & $65.44(\mathrm{abC}) \pm 0.94$ \\
\hline & 0.020 & $5.91 \pm 0.15$ & $4.74(\mathrm{bCD}) \pm 0.47$ & 19.90 & $71.88(\mathrm{bD}) \pm 0.89$ \\
\hline
\end{tabular}

Lowercase letters denote significant differences between the $\mathrm{Cu}$-leaching at the studied HA concentrations. Uppercase letters denote significant differences between $\mathrm{Cu}$-leaching by the wood preservative formulations for the same humic acid (HA) concentration. Data represented as mean \pm SD of three replicates $(p<0.05)$.

\subsection{Long Term Exposition Test of Wood Pole Segments}

According to visual inspection, the untreated wood segments and the CC treated segments showed similar decay symptoms with large decay pockets, deep cracks and checks (Figure 3). This type of decay was induced by fungal mycelium that can easily access all treated and untreated parts of the wood. However, wood segments treated with CCB and ACQ did not show any external damage even if the fungi had colonised central parts of the pole into which the preservative does not readily penetrate. Pole segments treated with $\mathrm{Cu}-\mathrm{HDO}$ showed early symptoms of decay such as small decay pockets and signs of incipient decay in central parts. The quantification of fungal decay by means of weight losses were in good agreement with visual observations. Weight losses of $\mathrm{Cu}$-impregnated wood pole segments caused by brown rot fungi is illustrated in Table 3. Significant weight losses were recorded from control samples $(29.9 \% \pm 7.9)$ and CC-treated wood $(20.4 \% \pm 3.5)$ when compared with the other treatments. Wood treated with CCB and ACQ showed the highest durability against the mixture of brown rot fungi with low weight loss $(0.0 \% \pm 4.7$ for CCB and $5.3 \% \pm 1.1$ for ACQ treated wood) after 24 months of incubation.

Table 3. Weight losses of treated wood pole segments by brown rot fungi after 24 months.

\begin{tabular}{lcc}
\hline Wood Pole Treatment & Weight Loss (\%) & Moisture Content (\%) \\
\hline Controls & $29.9(\mathrm{a}) \pm 7.9$ & $101.3(\mathrm{a}) \pm 4.6$ \\
CC & $20.4(\mathrm{ab}) \pm 3.5$ & $113.7(\mathrm{ab}) \pm 4.1$ \\
$\mathrm{ACQ}$ & $5.3(\mathrm{c}) \pm 1.1$ & $113.4(\mathrm{ab}) \pm 2.3$ \\
$\mathrm{CCB}$ & $0.0(\mathrm{c}) \pm 4.7$ & $133.2(\mathrm{ac}) \pm 7.3$ \\
$\mathrm{Cu}-\mathrm{HDO}$ & $10.8(\mathrm{cb}) \pm 1.8$ & $122.9(\mathrm{ab}) \pm 10.9$ \\
\hline
\end{tabular}

Lowercase letters denote significant differences between weight losses in wood treated specimens after 24 months incubation. Data represented as mean \pm SD of three replicates $(p<0.05)$. 


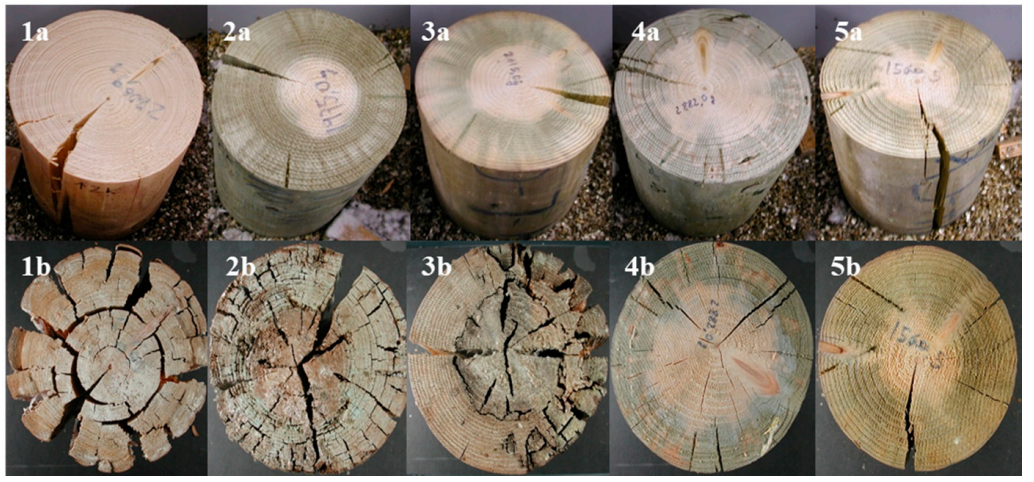

Figure 3. Effect of brown rot fungi on wood pole segments before (1a-5a) and after 24 months incubation (1b-5b). 1; Control. 2; copper-chromium (CC) treated poles. 3; (Bis-(N-cyclohexyldiazeniumdioxy) -copper) (Cu-HDO) treated poles. 4; copper-chromium-boron (CCB) treated poles. 5; Alkaline Copper Quaternary (ACQ) treated poles.

\subsection{Influence of Wood Decay on the Stiffness of Wood}

Changes in wood stiffness were directly correlated to weight losses caused by brown rot fungi (Figure 4). The variation in stiffness after fungal incubation was higher for non-impregnated than for impregnated wood specimens and significant differences between fungal species were found. For instance, non-impregnated wood specimens incubated with $A$. serialis were completely destroyed showing a reduction in stiffness of $86.02 \%$, whereas in wood specimens impregnated with $0.6 \%$ CC merely a low reduction in stiffness of $7.17 \%$ was recorded. Reduction in stiffness after fungal treatment was higher in the longitudinal samples than in radial wood specimens; however, significant differences were not recorded. No significant differences in weight losses caused by brown rot fungi were found between longitudinal and radial samples. The highest weight loss was recorded for A. serialis $(57.41 \%)$ on non-impregnated wood specimens (radial samples) while $S$. himantioides caused the highest weight losses (6.64\%) on Cu-impregnated wood specimens (longitudinal samples).

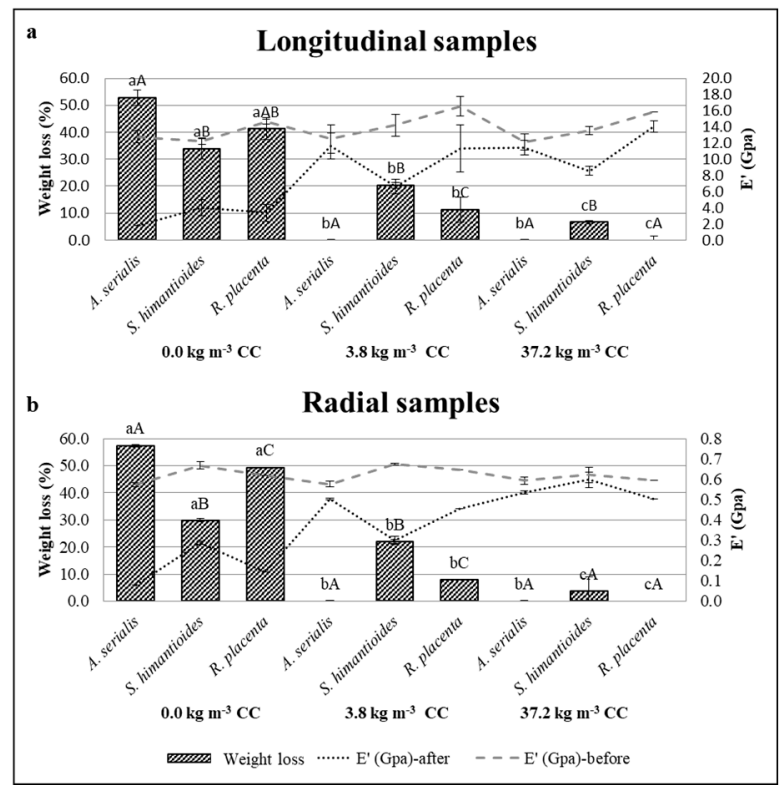

Figure 4. Effect of brown rot fungi on weight losses and stiffness of CC-treated wood after 12 weeks incubation. (a) Longitudinal samples. (b) Radial samples. Lowercase letters denote significant differences between the wood preservative concentrations for the same brown rot fungi. Uppercase letters denote significant differences between brown rot fungi for the same wood preservative concentrations. Data represented as mean \pm SD of three replicates $(p<0.05)$. 


\section{Discussion}

Our study investigated the $\mathrm{pH}$ of soils around utility poles and factors that influence fungal activity and may possibly have an impact on premature failure of utility poles in the field. The impact of soil $\mathrm{pH}$ on the microbial community composition and its activity is one of the most important influential factors in natural environments. Previous studies by Rousk et al. [38] showed that, regardless of the soil, the fungal growth was directly associated with a $\mathrm{pH}$ of up to 7 , but not above. This was confirmed in the present study that showed an average at approximately $\mathrm{pH}=6.7$ for all soil samples that were collected around utility poles that had previously failed in the field. The competitive fungal: bacterial growth ratio has also been demonstrated to be $\mathrm{pH}$ dependent in soils. Assuming that bacteria inhibit fungal growth at a $\mathrm{pH}$ above 7 and fungi take advantage of a $\mathrm{pH}$ below 7 [38], soils around the utility poles seem to have the perfect $\mathrm{pH}$ environment for brown rot fungi. In previous studies, Ribera et al. [13] showed that the failure of $\mathrm{Cu}$-treated utility poles was mainly associated with brown rot fungi (Antrodia spp.). In the latter study, a direct correlation between fungal species and geographic regions was not evident, but there was strong evidence that the type of wood preservative formulation had the highest selective pressure on wood decomposition by brown rot fungi. The results of the present study suggest that the soil $\mathrm{pH}$ may increase the microbial activity i.e., the biochemical cycling in soils in close proximity to $\mathrm{Cu}$-impregnated utility poles. Different parameters have been postulated to assess the influence on the advantages of different communities [39] such as initial inoculum and rapidly growing species. To date, differences in $\mathrm{pH}$ tolerance on $\mathrm{Cu}$-impregnated wood have not been addressed. Thus, our study suggests that brown rot fungi in the soil around utility poles may take advantage of the specific environmental conditions.

Brown rot fungi have evolved to specifically breakdown cellulose and other polysaccharides from wood. The mechanisms of wood cellulose depolymerisation by brown rot fungi have been hypothesised to occur via the production of extracellular toxic oxygen radicals such as the highly reactive hydroxyl radical via the Fenton reaction $[19,40]$. The role of iron in such reactions as well as other metabolic processes have been strongly documented. However, the bioavailability of iron is limited in the soil due to formation of insoluble metal oxides and hydroxides [41]. In our study, we showed that in the presence of iron dominant brown rot fungi such as A. serialis can cause considerable decay in impregnated wood specimens. In previous studies by Ribera et al. [13], the influence of available $\mathrm{Cu}$ was evaluated for a range of brown rot fungi. It was evident that the same concentrations of $\mathrm{Cu}$ caused toxicity to all the studied fungi, whereas in this study iron did not have any negative influence on the activity of the fungi. Thus, as iron is essential for life and the iron levels in wood are usually significantly low [42,43], the immobilisation/precipitation of essential ions from soils around the utility poles may also reduce the activity of brown rot fungi in the soil.

Leaching of wood preservatives has been previously described as $\mathrm{pH}$ dependent but the absence of $\mathrm{Cr}$ as a fixative for $\mathrm{Cu}$ in wood strongly influences leaching [17]. Furthermore, wood properties such as $\mathrm{pH}$, lignin type and content and extractive content can also influence the fixation of wood preservatives [44]. Copper and $\mathrm{Cr}$ compounds form more stable complexes with guaiacyl units of lignin which are the main monomer of softwood rather than the syringyl units that are the dominant monomer in secondary walls of hardwood fibres. This explains the fact that $\mathrm{Cu}$ in impregnated conifer wood migrates faster when substances with higher binding capacities are present such as HA or charcoal [17]. Humic substances represent the largest part of soil organic matter ( $60 \%)$ and are considered to be responsible for many complex chemical reactions in soils [45]. Humic substances have the ability to complex metal ions, oxides, hydroxides, pesticides and toxic pollutants. The formation of these complexes, can dissolve, immobilize and transport metals and organic compounds [46]. Thus, we assume that the organic matter content and other soil compounds such as HA may influence $\mathrm{Cu}$ migration as well as other wood preservative compounds in $\mathrm{Cu}$-impregnated wood. For instance, in this study, low concentrations of HA $(0.005 \%)$ produced higher amounts of $\mathrm{Cu}$ released in the water while higher concentrations $(0.020 \%)$ allowed lower $\mathrm{Cu}$-release. This could be related to the saturation of 
reactive sites in the HA by the released $\mathrm{Cu}$. Therefore, the possibility to modify and saturate the reactive sites available in soil substances can help to avoid rapid migration of $\mathrm{Cu}$ into organic substrates.

In general, there are many different factors affecting wood performance and the durability of utility poles, such as wood species (soft- or hardwood), heartwood/sapwood ratio, type and quality of preservative treatment and the environmental conditions. Vacuum-pressure impregnation aims to protect the sapwood in utility poles as it highly susceptible to wood decay fungi. Our study shows the importance of the proper selection of wood preservatives.

Brown rot fungi rapidly degrade glucosyl residues of the wood cellulose molecule [40]. The depolymerisation of cellulose causes a significant reduction in wood strength within relatively short periods ( $<10 \%$ weight loss) [47]. In the United States a fully loaded wood pole can lose $50 \%$ of its initial strength before replacement is required [48]. More recently, Yang et al. [49] studied the influence of brown rot and white rot fungi on the mechanical properties of pine wood samples after different incubation periods. The results showed that after 12 weeks, the changes in stiffness by brown rot fungi was almost five times greater than for white rot fungi. Moreover, they concluded that even before significant weight losses were recorded in wood by brown rot fungi, stiffness was already significantly reduced. This supports the theory that cellulose plays a major structural role on the wood mechanical properties [50] and brown rot fungi are of major concern for wood in service [13]. However, differences in the impact of brown rot fungi, as illustrated here, should be considered as many other factors can influence the metabolism of fungi.

\section{Conclusions}

Many different soil characteristics influence not only the activity of brown rot fungi, but also the performance of $\mathrm{Cu}$-based wood preservative formulations. Soil microbial composition as well as environmental conditions and the type of wood preservative formulations applied are responsible for premature failures of utility poles in service. Wood preservative formulations containing a co-biocide compound will improve the retention and performance of the chemical treatments. In this study, we demonstrated the influence of different parameters affecting the service life of utility poles in ground line contact such as the fact that concentrations up to $0.1 \%$ of Fe in the soil can increase wood decay significantly. The analysis of soil composition, type of wood decay fungi present in the soil and the choice of wood preservative formulation may help to improve the service life of impregnated wood in the field. Modification of the soil microenvironment surrounding the utility poles in ground contact may be a valid approach for controlling the activity of soil microorganisms and reduce wood decay susceptibility.

Supplementary Materials: The following are available online at http://www.mdpi.com/2076-3417/10/24/8837/s1, Table S1: Analysis of soil samples surrounding utility poles.

Author Contributions: For research articles with several authors, a short paragraph specifying their individual contributions must be provided. Conceptualization, J.R. and F.W.M.R.S.; methodology, J.R., E.M. and F.W.M.R.S.; software, J.R.; validation, J.R., E.M. and F.W.M.R.S.; formal analysis, J.R. and E.M.; investigation, J.R., E.M. and F.W.M.R.S.; resources, J.R., E.M. and F.W.M.R.S.; data curation, J.R.; writing —original draft preparation, J.R.; writing - review and editing, J.R., E.M. and F.W.M.R.S.; visualization, J.R.; supervision, F.W.M.R.S.; project administration, F.W.M.R.S.; funding acquisition, F.W.M.R.S. All authors have read and agreed to the published version of the manuscript.

Funding: This study was financially supported by the Swiss Commission for Technology and Innovation (CTI Project No. 17001.1 PFLS-LS).

Acknowledgments: The authors wish to thank MycoSolutions AG and Swisscom AG for their technical support.

Conflicts of Interest: The authors declare no conflict of interest. 


\section{References}

1. Pulleman, M.; Creamer, R.; Hamer, U.; Helder, J.; Pelosi, C.; Pérès, G.; Rutgers, M. Soil biodiversity, biological indicators and soil ecosystem services-An overview of European approaches. Curr. Opin. Environ. Sustain. 2012, 4, 529-538. [CrossRef]

2. Haq, I.U.; Zhang, M.; Yang, P.; van Elsas, J.D. The interactions of bacteria with fungi in soil: Emerging concepts. Adv. Appl. Microbiol. 2014, 89, 185-215. [PubMed]

3. Warmink, J.A.; Van Elsas, J.D. Selection of bacterial populations in the mycosphere of Laccaria proxima: Is type III secretion involved? ISME J. 2008, 2, 887-900. [CrossRef] [PubMed]

4. Mommer, L.; Weemstra, M. The role of roots in the resource economics spectrum. New Phytol. 2012, 195, 725-727. [CrossRef]

5. Bardgett, R.D.; Mommer, L.; De Vries, F.T. Going underground: Root traits as drivers of ecosystem processes. Trends Ecol. Evol. 2014, 29, 692-699. [CrossRef]

6. Bünemann, E.K.; Bongiorno, G.; Bai, Z.; Creamer, R.E.; de Deyn, G.; de Goede, R.; Fleskensd, L.; Geissend, V.; Kuyperb, T.W.; Mäder, P.; et al. Soil quality-A critical review. Soil Biol. Biochem. 2018, 120, $105-125$. [CrossRef]

7. Nortcliff, S. Standardisation of soil quality attributes. Agric. Ecosyst. Environ. 2002, 88, 161-168. [CrossRef]

8. Bárcenas-Moreno, G.; Gómez-Brandón, M.; Rousk, J.; Baath, E. Adaptation of soil microbial communities to temperature: Comparison of fungi and bacteria in a laboratory experiment. Glob. Chang. Biol. 2009, 15, 2950-2957. [CrossRef]

9. Barnard, R.L.; Osborne, C.A.; Firestone, M.K. Responses of soil bacterial and fungal communities to extreme desiccation and rewetting. ISME J. 2013, 7, 2229-2241. [CrossRef]

10. Edwards, I.P.; Zak, D.R.; Kellner, H.; Eisenlord, S.D.; Pregitzer, K.S. Simulated Atmospheric N Deposition Alters Fungal Community Composition and Suppresses Ligninolytic Gene Expression in a Northern Hardwood Forest. PLoS ONE 2011, 6, e20421. [CrossRef]

11. British Standards Institution (BSI). EN 460 Durability of Wood and Wood-Based Products Natural-Durability of Solid Wood-Guide to the Durability Requirements for Wood to be used in Hazard Classes; BSI: London, UK, 1994.

12. Bollmus, S.; Rangno, N.; Militz, H.; Gellerich, A. Analyses of Premature Failure of Utility Poles; The International Research Group on Wood Protection: Stockholm, Sweden, 2012.

13. Ribera, J.; Schubert, M.; Fink, S.; Cartabia, M.; Schwarze, F.W. Premature failure of utility poles in Switzerland and Germany related to wood decay basidiomycetes. Holzforschung 2017, 71, 241-247. [CrossRef]

14. Freeman, M.; McIntyre, C. A comprehensive review of copper-based wood preservatives with a focus on new micronized or dispersed copper systems. For. Prod. J. 2008, 58, 6-27.

15. Guo, H.; Bachtiar, E.V.; Ribera, J.; Heeb, M.; Schwarze, F.W.M.R.; Burgert, I. Non-biocidal preservation of wood against brown-rot fungi with a $\mathrm{TiO}_{2} /$ Ce xerogel. Green Chem. 2018, 20, 1375-1382. [CrossRef]

16. Ribera, J.; Fink, S.; Bas, M.D.C.; Schwarze, F.W.M.R. Integrated control of wood destroying basidiomycetes combining Cu-based wood preservatives and Trichoderma spp. PLoS ONE 2017, 12, e0174335. [CrossRef]

17. Ribera, J.; Gandía, M.; Marcos, J.F.; Bas, M.C.; Fink, S.; Schwarze, F.W.M.R. Effect of Trichoderma-enriched biochar in the integrated wood protection strategy. PLoS ONE 2017, 12, e0183004. [CrossRef]

18. Arantes, V.; Qian, Y.; Kelley, S.S.; Milagres, A.M.F.; Filley, T.R.; Jellison, J.; Goodell, B. Biomimetic oxidative treatment of spruce wood studied by pyrolysis-molecular beam mass spectrometry coupled with multivariate analysis and 13C-labeled tetramethylammonium hydroxide thermochemolysis: Implications for fungal degradation of wood. JBIC J. Biol. Inorg. Chem. 2009, 14, 1253-1263. [CrossRef]

19. Arantes, V.; Milagres, A.M.F.; Filley, T.R.; Goodell, B. Lignocellulosic polysaccharides and lignin degradation by wood decay fungi: The relevance of nonenzymatic Fenton-based reactions. J. Ind. Microbiol. Biotechnol. 2011, 38, 541-555. [CrossRef]

20. Kleman-Leyer, K.; Agosin, E.; Conner, A.H.; Kirk, T.K. Changes in Molecular Size Distribution of Cellulose during Attack by White Rot and Brown Rot Fungi. Appl. Environ. Microbiol. 1992, 58, 1266-1270. [CrossRef]

21. Fomina, M.; Hillier, S.; Charnock, J.M.; Melville, K.; Alexander, I.J.; Gadd, G.M. Role of oxalic acid over-excretion in toxic metal mineral transformations by Beauveria caledonica. Appl. Environ. Microbiol. 2005, 71,371-381. [CrossRef] 
22. Gadd, G.M.; Bahri-Esfahani, J.; Li, Q.; Rhee, Y.J.; Wei, Z.; Fomina, M.; Liang, X. Oxalate production by fungi: Significance in geomycology, biodeterioration and bioremediation. Fungal Biol. Rev. 2014, $28,36-55$. [CrossRef]

23. Munir, E.; Yoon, J.J.; Tokimatsu, T.; Hattori, T.; Shimada, M. A physiological role for oxalic acid biosynthesis in the wood-rotting basidiomycete Fomitopsis palustris. Proc. Natl. Acad. Sci. USA 2001, 98, 11126-11130. [CrossRef]

24. Rigling, D.; Günthardt-Goerg, M.S.; Blauenstein, H.; Frey, B. Accumulation of heavy metals into Armillaria rhizomorphs from contaminated soils. For. Snow Landsc. Res. 2006, 80, 213-220.

25. Rizzo, D.M.; Blanchette, R.A.; Palmer, M.A. Biosorption of metal ions by Armillaria rhizomorphs. Can. J. Bot. 1992, 70, 1515-1520. [CrossRef]

26. Tang, J.D.; Parker, L.A.; Perkins, A.D.; Sonstegard, T.S.; Schroeder, S.G.; Nicholas, D.D.; Diehl, S.V. Gene Expression Analysis of Copper Tolerance and Wood Decay in the Brown Rot Fungus Fibroporia radiculosa. Appl. Environ. Microbiol. 2012, 79, 1523-1533. [CrossRef]

27. Schwarze, F.W.M.R.; Baum, S. Mechanisms of reaction zone penetration by decay fungi in wood of beech (Fagus sylvatica). New Phytol. 2000, 146, 129-140. [CrossRef]

28. Schwarze, F.W.M.R. Wood decay under the microscope. Fungal Biol. Rev. 2007, 21, 133-170. [CrossRef]

29. Curling, S.F.; Clausen, C.A.; Winandy, J.E. Relationships between mechanical properties, weight loss, and chemical composition of wood during incipient brown-rot decay. For. Prod. J. 2002, 52, 34-39.

30. De Beeck, M.O.; Ruytinx, J.; Smits, M.M.; Vangronsveld, J.; Colpaert, J.V.; Rineau, F. Belowground fungal communities in pioneer Scots pine stands growing on heavy metal polluted and non-polluted soils. Soil Biol. Biochem. 2015, 86, 58-66. [CrossRef]

31. Emmet-Booth, J.P.; Forristal, P.D.; Fenton, O.; Ball, B.C.; Holden, N.M. A review of visual soil evaluation techniques for soil structure. Soil Use Manag. 2016, 32, 623-634. [CrossRef]

32. Guimarães, R.M.L.; Ball, B.C.; Tormena, C.A. Improvements in the visual evaluation of soil structure. Soil Use Manag. 2011, 27, 395-403. [CrossRef]

33. European Committee for Standardization (CEN). EN 807 Wood Preservatives. Determination of the Effectiveness against Soft Rotting Micro-Fungi and Other Soil Inhabiting Micro-Organisms; BSI: London, UK, 2001.

34. European Committee for Standardization (CEN). EN 113 Wood Preservatives-Test Method for Determining the Protective Effectiveness against Wood Destroying Basidiomycetes: Determination of Toxic Values; BSI: London, UK, 1996.

35. Obataya, E.; Ono, T.; Norimoto, M. Vibrational properties of wood along the grain. J. Mater. Sci. 2000, 35, 2993-3001. [CrossRef]

36. Ono, T.; Norimoto, M. Study on Young's Modulus and Internal Friction of Wood in Relation to the Evaluation of Wood for Musical Instruments. Jpn. J. Appl. Phys. 1983, 22, 611-614. [CrossRef]

37. Sedighi-Gilani, M.; Tingaut, P.; Heeb, M.; Schwarze, F.W.M.R. Influence of moisture on the vibro-mechanical properties of bio-engineered wood. J. Mater. Sci. 2014, 49, 7679-7687. [CrossRef]

38. Rousk, J.; Brookes, P.C.; Bååth, E. Investigating the mechanisms for the opposing $\mathrm{pH}$ relationships of fungal and bacterial growth in soil. Soil Biol. Biochem. 2010, 42, 926-934. [CrossRef]

39. Bárcenas-Moreno, G.; Bååth, E.; Rousk, J. Functional implications of the pH-trait distribution of the microbial community in a re-inoculation experiment across a pH gradient. Soil Biol. Biochem. 2016, 93, 69-78. [CrossRef]

40. Illman, B.L. Oxidative degradation of wood by brown-rot fungi. In Active Oxygen/Oxidative Stress and Plant Metabolism; Pell, E.J., Steffen, K.L., Eds.; American Society of Plant Physiologists Press: Rockville, MD, USA, 1991; pp. 97-106.

41. Jellison, J.; Connolly, J.; Goodell, B.; Doyle, B.; Illman, B.; Fekete, F.; Ostrofsky, A. The role of cations in the biodegradation of wood by the brown rot fungi. Int. Biodeterior. Biodegrad. 1997, 39, 165-179. [CrossRef]

42. Jellison, J.; Smith, K.; Shortle, W. Cation analysis of wood degraded by white- and brown-rot fungi. In International Research Group on Wood Preservation Series; IRG/WP 1552-92; The International Research Group on Wood Protection: Stockholm, Sweden, 1992.

43. Jellison, J.; Connolly, J.; Smith, K.; Shortle, W. A comparison of inductively coupled plasma spectroscopy and neutron activation analysis for the determination of cation concentrations. In International Research Group on Wood Preservation Series; IRG/WP 10048-93; The International Research Group on Wood Protection: Stockholm, Sweden, 1993. 
44. Lebow, S. Leaching of wood preservative components and their mobility in the environment: Summary of pertinent literature. In Forest Products Laboratory General Technical Report FPL-GTR-93; USDA Forest Service: Washington, DC, USA, 1995; Volume 93, p. 36.

45. Stevenson, F.J. Organic forms of soil nitrogen. In Humic Chemistry: Genesis, Composition, Reaction; Wiley, J., Ed.; Wiley: Hoboken, NJ, USA, 1994; pp. 59-95.

46. Trevisan, S.; Francioso, O.; Quaggiotti, S.; Nardi, S. Humic substances biological activity at the plant-soil interface: From environmental aspects to molecular factors. Plant Signal Behav. 2010, 5, 635-643. [CrossRef]

47. Wilcox, W.W.; Dietz, M. Fungi causing above ground wood decay in structures in California. Wood Fiber Sci. 1997, 29, 291-298.

48. Brown, R.E. Electric Power Distribution Reliability, 2nd ed.; Marcel Dekker: New York, NY, USA, 2009.

49. Yang, Z.; Jiang, Z.; Hse, C.Y.; Liu, R. Assessing the impact of wood decay fungi on the modulus of elasticity of slash pine (Pinus elliottii) by stress wave non-destructive testing. Int. Biodeterior. Biodegrad. 2017, 117, 123-127. [CrossRef]

50. Goodell, B.; Daniel, G.; Liu, J.; Mott, L.; Frank, R. Decay resistance and microscopic analysis of wood-cement composites. For. Prod. J. 1997, 47, 75-80.

Publisher's Note: MDPI stays neutral with regard to jurisdictional claims in published maps and institutional affiliations.

(C) 2020 by the authors. Licensee MDPI, Basel, Switzerland. This article is an open access article distributed under the terms and conditions of the Creative Commons Attribution (CC BY) license (http://creativecommons.org/licenses/by/4.0/). 